\title{
Assessment of Metallic Content, Pollution, and Sources of Road Dust in the City of Białystok (Poland)
}

\author{
Mirosław Skorbiłowicz*, Elżbieta Skorbiłowicz, Wojciech Lapiński \\ Biatystok University of Technology, Faculty of Building and Environmental Engineering; ul. Wiejska 45E, 15-351 \\ Biatystok, Poland
}

\begin{abstract}
This study used flame atomic absorption spectrometry (FAAS) to determine the metallic content in 69 samples of street dust collected in various environments (viz., streets with heavy traffic, streets in residential neighborhoods, and streets near green areas and parks) of Białystok, Poland, during 2018. In descending order of average concentration, the measured metals were Fe (2,335 mg kg$\left.{ }^{-1}\right), \mathrm{Zn}\left(68.99 \mathrm{mg} \mathrm{kg}^{-1}\right), \mathrm{Mn}\left(68.62 \mathrm{mg} \mathrm{kg}^{-1}\right), \mathrm{Cu}\left(16.37 \mathrm{mg} \mathrm{kg}^{-1}\right), \mathrm{Pb}\left(11.42 \mathrm{mg} \mathrm{kg}{ }^{-1}\right), \mathrm{Cr}$ $\left(9.12 \mathrm{mg} \mathrm{kg}^{-1}\right)$, and $\mathrm{Ni}\left(5.20 \mathrm{mg} \mathrm{kg}^{-1}\right)$. Only $\mathrm{Zn}$ and $\mathrm{Cu}$ exhibited concentrations exceeding the geochemical background levels for Polish soil. We mapped the metallic concentrations in the samples to evaluate the spatial distribution of these elements and identified proximity to main road junctions with high traffic as a major factor. Multivariate statistical analysis (Pearson correlation, cluster analysis, and analysis of major components) revealed an association between vehicle operation, and $\mathrm{Zn}, \mathrm{Ni}, \mathrm{Cu}$, and $\mathrm{Cr}$, as these elements were found in the most traffic-congested areas. By contrast, Fe and $\mathrm{Mn}$, which were detected in potentially unpolluted areas, displayed concentrations that were similar to natural ones.
\end{abstract}

Keywords: Metals; Road dust; Identification of pollution sources.

\section{INTRODUCTION}

Air pollutants emitted by motor vehicles are the largest component of air pollution recorded as a result of human activity, posing a threat to human health and natural resources (Meister et al., 2012; EEA, 2016). Along with the intensive development of urban agglomerations, hence an increase in the number of motor vehicles, the amount of toxic pollution in urban environment increases (Han et al., 2014; Suryawanshi et al., 2016).

Air pollution, the source of which is transportation, is related to the emission of solid particles from combustion engines (Van der Gon et al., 2013). According to many authors, the dominant emission of molecules getting into the environment from road traffic arises from abrasion of brake pads, discs and clutches, tire wear, corrosion of the car body, road infrastructure and destruction of the road surface (Carrero et al., 2012; Adamiec et al., 2016). Rexeis and Hausberger (2009) even predicted that the share of non-fuel particles would continue to increase and by the end of 2020 it will average around $90 \%$ of the pollutant emissions from transportation sources.

\footnotetext{
* Corresponding author.

Tel.: +48 797996001

E-mail address: m.skorbilowicz@pb.edu.pl
}

It is widely believed that the problem of heavy metal pollution is related to areas of intensive industry, but according to Bhattacharya et al. (2013), it is actually roads and car traffic that are considered to be one of the largest sources of metals.

Composition and amount of toxic elements in street dust are indicators of the quality of the urban environment (Han et al., 2014). The dust also includes natural materials such as leaves and other fragments of plants that can be pulverized by traffic (Qiao et al., 2011). Road dust contains high levels of sulfates, chlorides, nitrogen compounds, phosphates, calcium, potassium, sodium, magnesium, and heavy metals that limit their use and management (Bartkowiak et al., 2017). Although heavy metals in trace amounts are ubiquitous in natural water, air, soil and sediments, and some of them are essential for life, they can be toxic when occurring in excessive amounts (Tanushree et al., 2011). Small particles that make up the street dust are able to resuspend in the atmosphere and are transported over long distances by the wind (Acosta et al., 2014; Gawade et al., 2016).

In recent years, public and scientific attention has increasingly focused on road dust pollution (Rasmussen $e t$ al., 2001; Christoforidis and Samatis, 2009; Tanushree et al., 2011; Khairy et al., 2011; Amato et al., 2014; Kiebała et al., 2015; Adamiec, 2017; Suryawanshi et al., 2016; Trojanowska and Świetlik, 2016; Alsbou and Al-Khashman, 2018), and it seems advisable to include metallic content in street dust in routine monitoring tests. 
Investigation of road dust is important for many reasons (El-Sergany and El-Sharkawy, 2011). Firstly, road dusts are inhaled by those who traverse the streets/highways and those who reside in the vicinity of major roads. In road dust pollution events, metals are released into the environment. Consequently, the public is exposed to the health hazards associated with such metals (Victoria et al., 2014). Secondly, during the periods of rainfall and strong winds, dust particles are deposited into the adjoining marine environment leading to sedimentation and metal contamination, thereby posing negative ecological impacts on aquatic organisms. Consumption of metal-contaminated seafood can adversely affect the human health (Martin and Griswold, 2009).

Intake of dust particles laden with high concentrations of heavy metals may cause respiratory and cardiovascular diseases, cancer, birth defects, central nervous system impairment and death (Adewale et al., 2010a; Tchounwou et al., 2012). It is estimated that traffic dusts contribute to 1.5-2 million annual premature deaths worldwide (Greening, 2011). Furthermore, road dust pollution has negative impacts on agriculture, environment and public health (Greening, 2011).

In the case of Poland, monitoring of street dust is particularly advisable. According to statistical data, in 2018, approximately 1 million old cars used over 12 years were imported to Poland, of which $43 \%$ were cars with diesel engines (Central Statistical Office, 2018).

The subject of this work is street dust testing based on material collected in Białystok. Białystok (294,153 inhabitants) is a city located in the north-east of Poland and is not a large enough city to develop transport infrastructure including metro or streetcars, instead there are only public transport buses $(70 \%$ are passenger cars and $30 \%$ public bus transport). Białystok is home to high-traffic roads leading to the Polish capital of Warsaw and border crossings with the Belarussian Republic (Bobrowniki, Kuźnica Białostocka) and the Republic of Lithuania (Budzisko, Ogrodniki). In Białystok, street dust tests were not carried out yet, only the content of trace elements in urban soil was studied (Skorbiłowicz et al., 2001; Czubaszek and Bartoszuk, 2011)

The objectives of the work were as follows: (1) assessment of the degree of metallic pollution $(\mathrm{Zn}, \mathrm{Cu}, \mathrm{Pb}, \mathrm{Ni}, \mathrm{Cr}, \mathrm{Mn}$, $\mathrm{Fe}$ ) of road dust collected in Białystok city from various environments (roads with heavy traffic, housing streets, streets located near parks and green areas), (2) determining the impact of car transport on the spatial diversity of metallic content in the street dust, (3) identification of the main sources of individual metals in street dust using a multidimensional statistical analysis.

\section{METHODS}

\section{Background of Tests}

The city of Białystok $\left(53^{\circ} 07^{\prime} 59^{\prime \prime} \mathrm{N}\right.$ and $\left.23^{\circ} 09^{\prime} 51^{\prime \prime} \mathrm{E}\right)$ is located in north-eastern Poland and covers an area of $102.12 \mathrm{~km}^{2}$. There are 294,153 inhabitants in Białystok and the population density is 2,880 people per $\mathrm{km}^{2}$. The largest area in the land use structure is occupied by built-up and urbanized lands, and $32 \%$ of its area is occupied by green areas (Municipal Office in Białystok, 2010). Białystok is the main transport hub of the Podlaskie Voivodeship and an important national transport hub. It is the intersection of the main road and rail traffic routes. Car transport has the greatest impact on the state of the environment in the transport sector. The low fluidity of traffic, especially at traffic peaks, also has a significant impact on emissionsthe emission of substances when starting and braking is higher than during smooth driving. Another important source influencing the air quality is the emission from individual furnaces and local boiler plants, i.e., dispersed emission sources from the municipal and household sector and the emission from industrial sources. A significant share in the emission comes also from thermal power engineering and other large plants in and around Białystok (Municipal Office in Białystok, 2010). Within Białystok borders, there are two nature reserves that are remnants of the Knyszynska Forest. Within the agglomeration, there is also a part of the Narwiański National Park. The city has a temperate climate with the following yearly averages: temperature of $6.6^{\circ} \mathrm{C}$, precipitation of $586 \mathrm{~mm}$, wind speed of $10.1 \mathrm{~km} \mathrm{~h}^{-1}$. The city is dominated by brown and podzolic soils.

\section{Sample Collection and Preparation}

Research points have been divided into three groups: heavy congestion (13,680-30,720 vehicles day $\left.{ }^{-1}\right)$, light congestion (estate streets; 4,800-18,000 vehicles day ${ }^{-1}$ ), and potentially unpolluted areas without heavy traffic (area around parks and green areas; 2,640-9,120 vehicles day ${ }^{-1}$ ). In total, samples from 69 points were analyzed (Fig. 1), which were collected in spring in dry weather in 2018. This approach is particularly important to minimize any metal leaching effects. Road dust was collected from both sides of the roadway, adjacent to its edge. The area from which each sample was taken was $1 \mathrm{~m}^{2}$. Samples were collected by sweeping about $500 \mathrm{~g}$ of material with a brush and clean plastic scoop for plastic self-sealing polyethylene bags and transported to the laboratory. Then, the street dust was dried in the laboratory at room temperature. After drying, it was sieved through a $1 \mathrm{~mm}$ nylon sieve to remove large stones and plant residues, then dried again in an oven at $110^{\circ} \mathrm{C}$. Dried samples were ground in an automatic agate mortar. All sampling and handling procedures have been carried out without contact with metals to avoid potential contamination.

\section{Analytical Procedures}

Samples of $0.5 \mathrm{~g}$ street dust were wet combusted in hydrochloric and nitric acid mixture in a 3:1 volume ratio in a closed CEM microwave system. All determinations were carried out in triplicate. The samples after filtration were quantitatively transferred to $50 \mathrm{~mL}$ graduated flasks. The content of metals ( $\mathrm{Zn}, \mathrm{Cu}, \mathrm{Pb}, \mathrm{Ni}, \mathrm{Cr}, \mathrm{Mn}, \mathrm{Fe}$ ) was determined by flame atomic absorption spectrometry (FAAS) on the AAS ICE 3500 Thermo Scientific spectrometer. All solutions were prepared using ultrapure water. Glass that was used for the tests was soaked in nitric acid (8\%) and washed with tap water, and then thoroughly rinsed with deionized water. The results of street dust analysis were verified using a certified 


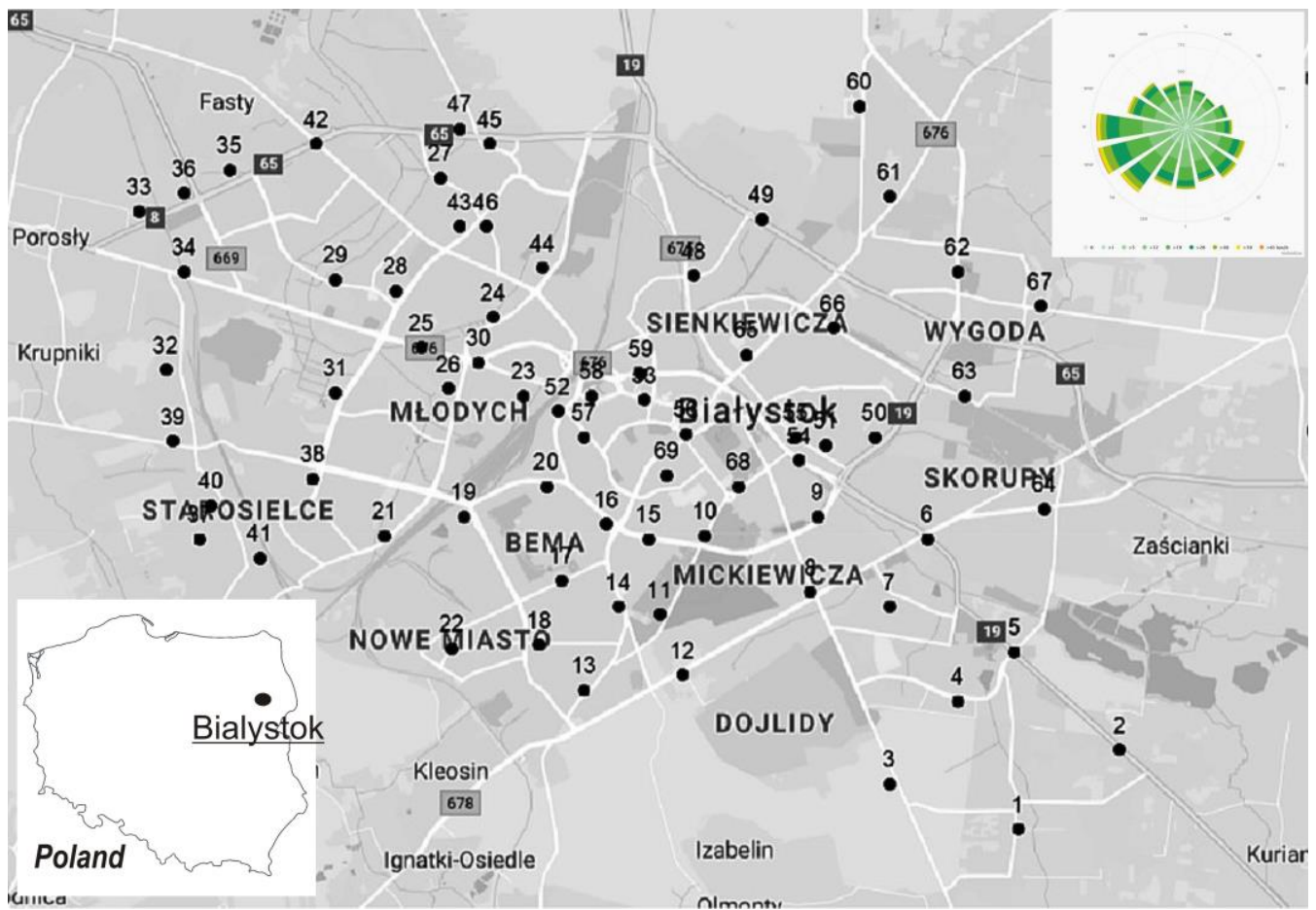

Fig. 1. Location of the studied area with 69 measuring points and a wind map showing the prevailing wind direction in Bialystok.

reference material (Certificate No. 0217-CM-700I-04, 7003). Results of standard reference material measurements revealed good agreement with certified values ( $\mathrm{Zn}: 96 \%$; $\mathrm{Cu}: 101 \%$; Pb: 95\%; Ni: 89\%; Cr: 80\%; Mn: 97\%; Fe: 98\%). Similar results $(91.3-108.5 \%)$ were obtained by Wu et al. (2019).

\section{Evaluation of the Road Dust Pollution Degree}

The geochemical background of Polish soils proposed by Czarnowska (1996) (Table 1) and the degree of pollution using the geochemical index $\left(\mathrm{I}_{\text {geo }}\right)$ was used to assess the degree of street dust pollution.

Geochemical index $\left(\mathrm{I}_{g e o}\right)(1)$ is defined using the formula (Müller, 1969):

$$
I_{\text {geo }}=\log _{2}\left(\frac{C_{n}}{1.5 \cdot B n}\right)
$$

where $C_{n}$ is the measured content of the determined metal $\left(\mathrm{mg} \mathrm{kg}^{-1}\right), \mathrm{B}_{\mathrm{n}}$ is the geochemical background concentration proposed by Wedepohl (1995) (Table 1), and 1.5 is the correlation coefficient of the background matrix due to lithological variability. Values of $\mathrm{I}_{g e o}$ are classified according to Müller (1969) and are divided into seven classes: uncontaminated, Class $0\left(\mathrm{I}_{\text {geo }} \leq 0\right)$; uncontaminated to medium contaminated, Class $1\left(0<\mathrm{I}_{\text {geo }}<1\right)$; moderately contaminated, Class $2\left(1<\mathrm{I}_{g e o}<2\right)$; moderately or heavily contaminated, Class $3\left(2<\mathrm{I}_{\text {geo }}<3\right)$; heavily contaminated, Class $4\left(3<\mathrm{I}_{\text {geo }}\right.$ $<4)$; heavily to very heavily contaminated, Class $5\left(4<\mathrm{I}_{\text {geo }}\right.$ $<5)$; very heavily contaminated, Class $6\left(\mathrm{I}_{\text {geo }} \geq 5\right)$.

Obtained results of the content of tested metals were given in relation to air-dry dusts and compared with literature data from different cities in the world.

\section{Statistical Analysis}

All statistical analyses were performed using the licensed software Statistica ver. 13.3 for Windows. The Shapiro-Wilk test was used to verify normal distribution. Results were considered statistically significant at the probability of making an error $\mathrm{p}<0.05$. The analysis of Pearson's correlation and the Surfer 8.0 for Windows software were used to examine the relationships between metals in road dust and to identify their sources. Geographical information system was used to analyze the spatial characteristics of heavy metals in road dust (Li et al., 2016). Before the principal component analysis (PCA), the KMO (Kaiser-Meyer-Olkin) index and Bartlett's sphericity test were performed. The KMO value was obtained in the range from 0.55 to 0.60 and Bartlett's test was statistically significant. The correlation coefficient was used to measure the mutual relationships between two metals. Correlation of different elements is an important basis of source identification, which can help confirm and obtain interpretation of PCA results (Jiang et al., 2019). Multivariate statistical analysis was also applied in analyses, which is often used to identify sources of dust (Lu et al., 2010; Chen et al., 2011). Statistical cluster analysis (CA) in the Ward version was used in order to classify metals from various sources, but having similar physical and chemical properties (Christoforidis and Stamatis, 2009).

\section{RESULTS AND DISCUSSION}

\section{The Content of Heavy Metals in Road Dust}

Seven metals were tested ( $\mathrm{Zn}, \mathrm{Cu}, \mathrm{Pb}, \mathrm{Ni}, \mathrm{Cr}, \mathrm{Mn}$ and $\mathrm{Fe}$ ) 
in 69 samples of road dust collected in Białystok along streets with high and low traffic in Table 1.

It was found that the average metallic content in road dust is dominated mainly by $\mathrm{Fe}$, then $\mathrm{Zn}>\mathrm{Mn}>\mathrm{Cu}>\mathrm{Pb}>\mathrm{Cr}>$ Ni. The order of metals by abundance was $\mathrm{Fe}>\mathrm{Zn}>\mathrm{Mn}>$ $\mathrm{Pb}>\mathrm{Cr}>\mathrm{K}>\mathrm{Cu} \mathrm{Na}>\mathrm{Ba}>\mathrm{Ni}>\mathrm{V}>\mathrm{Cd}$ in road dust samples (Taivo et al., 2017). Iron content in road dust did not exceed the level of geochemical background for soils in Poland (Czarnowska, 1996) and varied from $400.00 \mathrm{mg} \mathrm{kg}^{-1}$ to $10,130.00 \mathrm{mg} \mathrm{kg}^{-1}$, reaching the average value of 2,335.00 mg kg-1. According to Han et al. (2014), Fe may originate from natural sources such as the earth's crust, soil, as well as from dust carried by wind from unpaved roads reduce the acceleration of a vehicle in heavy traffic. The highest concentration of $\mathrm{Fe}$ in the dust was recorded in the center of Białystok. Analysis also showed that Fe content in areas with high congestion (city center) is significantly higher (average: $2,355.00 \mathrm{mg} \mathrm{kg}^{-1}$ ) than on roads with low congestion (average: $1,472.31 \mathrm{mg} \mathrm{kg}^{-1}$ ). The smallest $\mathrm{Fe}$ content occurred in the south-eastern part of Białystok, where there are many green areas. In contrast, the content of $\mathrm{Mn}$ and $\mathrm{Zn}$ varied and occurred in the road dust in the range 6.74-194.13 mg Mn kg-1 and 21.43-172.19 $\mathrm{mg} \mathrm{Zn} \mathrm{kg}^{-1}$. The content of $\mathrm{Mn}$ in $74 \%$ of samples was in the range of $20-70$ $\mathrm{mg} \mathrm{kg}^{-1}$ at the geochemical background for Mn $289 \mathrm{mg} \mathrm{kg}^{-1}$, thus it has not been exceeded. The highest Mn content in road dust samples was found in the north-western part of the city, on a busy road towards Warsaw. According to Han et al. (2014), Mn originates from soil and car emissions. Also Bardelli et al. (2011) claimed that the main source of Mn in road dust is transport, moreover, it gets mainly from unleaded petrol-powered vehicles - once added to gasoline $\mathrm{Pb}$ compounds were replaced with $\mathrm{Mn}$ and hence its increased emission. In turn, the smallest content of Mn was obtained in the south-eastern part of the city, in which green areas and single-family buildings prevail. In the case of $\mathrm{Zn}$, only 8 road dust samples had a natural content where the background for $\mathrm{Zn}$ in soil in Poland is $30 \mathrm{mg} \mathrm{kg}^{-1}$ (Czarnowska, 1996). The highest $\mathrm{Zn}$ content occurred in dust samples taken in the north-western part of the city, mainly on the National Road No. 8, where high traffic of cars reaching up to 30,000 vehicles daily occurs. It is the road connecting Białystok with the capital of Poland, Warsaw. Significant $\mathrm{Zn}$ content was also obtained in samples taken from the city center, where there is also a lot of traffic_-about 24,000 cars per day. Many authors indicate that large amounts of $\mathrm{Zn}$ are emitted as a result of tire wear during vehicle operation (Schauer et al., 2006; Bhattacharya et al., 2013). Ozaki et al. (2004) claimed that tires contain about $1.3-1.7 \% \mathrm{Zn}$, while Smolders and Degryse (2002), up to $4.3 \% \mathrm{Zn}$. Carrero (2012) also believes that $\mathrm{Zn}$ can originate from abrasion of traffic lights and barriers. $\mathrm{Zn}$ derived from these sources occurs in mobile forms and may potentially affect the water and soil environment. The average $\mathrm{Cu}$ content for the area with high congestion was $16.37 \mathrm{mg} \mathrm{kg}^{-1}$; with low congestion, $11.49 \mathrm{mg} \mathrm{kg}^{-1}$; and on unpolluted area, $10.09 \mathrm{mg} \mathrm{kg}^{-1}$, which exceeded the value of geochemical background equal to $7.1 \mathrm{mg} \mathrm{kg}^{-1}$ (Czarnowska, 1996). In three samples, $\mathrm{Cu}$ content was even above $55 \mathrm{mg} \mathrm{kg}^{-1}$. Analyzing $\mathrm{Cu}$ content in road dust, it should be noted that it is a common element in automotive bearings, brake linings and other engine parts (Adamiec, 2017), and because operation of a car causes metal consumption, $\mathrm{Cu}$ is released into the environment (Schauer et al., 2006). The tests showed low content of $\mathrm{Cr}$, $\mathrm{Pb}$ and $\mathrm{Ni}$ in road dust in the following ranges: 4.01-21.52, $1.24-78.19,0.12-13.77 \mathrm{mg} \mathrm{kg}^{-1}$, respectively; in most

Table 1. Descriptive statistics of metal concentrations in road dusts of Bialystok.

\begin{tabular}{|c|c|c|c|c|c|c|c|c|}
\hline \multicolumn{2}{|l|}{ Metal $\left(\mathrm{mg} \mathrm{kg}^{-1}\right)$} & $\mathrm{Zn}$ & $\mathrm{Cu}$ & $\mathrm{Pb}$ & $\mathrm{Ni}$ & $\mathrm{Cr}$ & $\mathrm{Mn}$ & $\mathrm{Fe}$ \\
\hline \multirow{6}{*}{$\begin{array}{l}\text { Large congestion } \\
n=32\end{array}$} & Min & 21.43 & 2.90 & 1.35 & 0.12 & 4.60 & 23.49 & 400.00 \\
\hline & Max & 172.19 & 72.65 & 78.19 & 13.77 & 21.52 & 194.13 & 10130.00 \\
\hline & Mean & 68.99 & 16.37 & 11.42 & 5.20 & 9.12 & 68.62 & 2355.00 \\
\hline & $\mathrm{SD}$ & 40.22 & 14.90 & 15.24 & 2.70 & 3.10 & 32.62 & 2245.74 \\
\hline & $\mathrm{CV}[\%]$ & 58 & 91 & 133 & 52 & 34 & 48 & 95 \\
\hline & S-W test & 0.005 & 0.000 & 0.000 & 0.000 & 0.00 & 0.000 & 0.000 \\
\hline \multirow{6}{*}{$\begin{array}{l}\text { Small congestion } \\
n=26\end{array}$} & Min & 28.45 & 3.08 & 1.78 & 1.00 & 4.01 & 28.66 & 520.00 \\
\hline & $\operatorname{Max}$ & 127.22 & 47.75 & 14.94 & 6.83 & 11.91 & 84.13 & 3280.00 \\
\hline & Mean & 51.79 & 11.49 & 5.79 & 4.72 & 7.70 & 59.73 & 1472.31 \\
\hline & SD & 23.54 & 9.65 & 2.94 & 1.11 & 2.19 & 10.50 & 800,47 \\
\hline & $\mathrm{CV}[\%]$ & 45 & 84 & 51 & 23 & 29 & 18 & 54 \\
\hline & S-W test & 0.000 & 0.000 & 0.007 & 0.020 & 0,669 & 0.072 & 0.004 \\
\hline \multirow{6}{*}{$\begin{array}{l}\text { Parks and green areas } \\
n=11\end{array}$} & Min & 23.18 & 1.89 & 1.24 & 0.21 & 4.56 & 6.74 & 590.00 \\
\hline & Max & 59.52 & 30.03 & 5.11 & 5.61 & 10.14 & 74.41 & 2150.00 \\
\hline & Mean & 41.84 & 10.09 & 3.67 & 3.81 & 7.38 & 48.46 & 1387.27 \\
\hline & SD & 11.88 & 8.04 & 1.30 & 1.79 & 1.77 & 20.24 & 540.74 \\
\hline & $\mathrm{CV}[\%]$ & 28 & 80 & 35 & 47 & 24 & 42 & 39 \\
\hline & S-W test & 0.585 & 0.003 & 0.057 & 0.000 & 0.810 & 0.165 & 0.536 \\
\hline \multicolumn{2}{|c|}{ background levels ${ }^{\mathrm{a}}$ Mean } & $30^{\mathrm{a}} 95^{\mathrm{b}}$ & $7.1^{\mathrm{a}} 45^{\mathrm{b}}$ & $9.8^{\mathrm{a}} 20^{\mathrm{b}}$ & $10.7^{\mathrm{a}} 68^{\mathrm{b}}$ & $27.0^{\mathrm{a}} 90^{\mathrm{b}}$ & $289^{\mathrm{a}} 850^{\mathrm{b}}$ & $12900^{\mathrm{a}} 47700^{\mathrm{b}}$ \\
\hline
\end{tabular}

Min: minimum; Max: maximum; Mean: arithmetic mean; SD: standard deviation; CV[\%]: coefficient of variance.

S-W test: Shapiro-Wilk test.

${ }^{\mathrm{a}}$ Czarnecka (1996), ${ }^{\mathrm{b}}$ Wedepohl (1995). 
cases, they were on the natural level, which shows that metals were not emitted by road transport in a significant way. Ni and $\mathrm{Cr}$ in road dust may be associated with processes occurring on the road surface and may come from tire and road friction processes as well as from the marking paint and anti-corrosion coatings on vehicles and safety barriers (Bhattacharya et al., 2013). In our research, larger amounts of $\mathrm{Pb}$ occurred in areas with heavy congestion (north-western part of Białystok-Road No. 8 connecting Białystok with Warsaw). The above analyses indicated that the exceedance of the geochemical background for Polish soils occurred for $\mathrm{Zn}$ and $\mathrm{Cu}$ in the road dust, while according to the proposed background by Wedepohl (1995), there were no exceedances for any of the elements studied (Table 1). We compared the metallic content in road dust in this study (2018) with cities in Poland and other countries (Table 2). As shown in Table 2, mean $\mathrm{Zn}, \mathrm{Cu}, \mathrm{Pb}, \mathrm{Ni}, \mathrm{Cr}, \mathrm{Mn}$ and $\mathrm{Fe}$ content in dust in Białystok were much smaller than in other cities in the world: Delhi, Birmingham, Luanda, Madrid, Kavala, Ottawa and Lublin. Białystok is less populated, which is associated with less traffic, therefore the concentration of metals in the dust is also lower, compared to large cities. The exceptions were average $\mathrm{Fe}$ and $\mathrm{Zn}$ content in dust collected in Warsaw, where lower values occurred, especially in the case of $\mathrm{Fe}$ (Warsaw: $600 \mathrm{mg} \mathrm{Fe} \mathrm{kg}{ }^{-1}, 63.60 \mathrm{mg} \mathrm{Zn} \mathrm{kg}{ }^{-1}$; Białystok: 2,335 $\mathrm{mg} \mathrm{Fe} \mathrm{kg}^{-1}, 68.99 \mathrm{mg} \mathrm{Zn} \mathrm{kg}^{-1}$ ). Similar results (Table 2) from the study of road dust from the city of Abeokuta in Nigeria were achieved by Taivo et al. (2017)

\section{Contamination Indicator $\left(I_{g e o}\right)$}

Values of $\mathrm{I}_{\text {geo }}$ calculated for each metal in Białystok road dust are presented in Table 3.

The geo-accumulation index is a commonly used parameter used to determine the pollution of road dust with toxic elements (Kiebala et al., 2015; Adamiec, 2017; Bourliva et $a l ., 2017)$. The average $\mathrm{I}_{g e o}$ values for individual elements are ranked as follows: $\mathrm{Zn}>\mathrm{Fe}>\mathrm{Pb}>\mathrm{Cu}>\mathrm{Cr}>\mathrm{Mn}>\mathrm{Ni}$. The highest mean $\mathrm{I}_{\text {geo }}$ values occurred in the case of $\mathrm{Zn}$. According to the degree of pollution standard by Müller (1969), the average $I_{g e o}$ values indicate that the road dusts tested in Białystok are uncontaminated. Analyzing the maximum $\mathrm{I}_{\text {geo }}$ values for $\mathrm{Pb}, \mathrm{Fe}, \mathrm{Zn}, \mathrm{Cu}$, amounting to 1.38 , $0.56,0.27,0.11$, respectively, it should be noted that the largest amounts of these metals occurred at these sampling points. Comparison of $\mathrm{I}_{g e o}$ values for metals from various functional areas indicates that $\mathrm{I}_{g e o}$ values in areas with high

Table 2. Average concentration $\left(\mathrm{mg} \mathrm{kg}^{-1}\right)$ of metals in road dust from various cities in the world.

\begin{tabular}{|c|c|c|c|c|c|c|c|c|c|}
\hline City & Population & $\mathrm{Zn}$ & $\mathrm{Cu}$ & $\mathrm{Pb}$ & $\mathrm{Ni}$ & $\mathrm{Cr}$ & $\mathrm{Mn}$ & $\mathrm{Fe}$ & Reference \\
\hline $\begin{array}{l}\text { Delhi } \\
\text { (Indie) }\end{array}$ & 1670000 & 263.7 & 168.7 & 128.7 & 37.2 & 170.8 & 699.2 & 27047 & Rajaram et al., 2014 \\
\hline $\begin{array}{l}\text { Birmingham } \\
\text { (Anglia) }\end{array}$ & 2300000 & 534.0 & 466.9 & 48.0 & 41.1 & - & - & - & $\begin{array}{l}\text { Charlesworth et al., } \\
2003\end{array}$ \\
\hline $\begin{array}{l}\text { Luanda } \\
\text { (Angola) }\end{array}$ & 2500000 & 317 & 42 & 351 & 10 & 26 & 258 & 11572 & $\begin{array}{l}\text { Ferreira-Baptista and } \\
\text { De Miguel, } 2005\end{array}$ \\
\hline $\begin{array}{l}\text { Madrid } \\
\text { (Spain) }\end{array}$ & 2909792 & 476 & 188 & 1927 & 44 & 61 & 362 & 19300 & De Miguel et al., 1997 \\
\hline $\begin{array}{l}\text { Kavala } \\
\text { (Greece) }\end{array}$ & 54027 & 272 & 124 & 301 & 58 & 196 & - & - & $\begin{array}{l}\text { Christoforidis and } \\
\text { Stamatis, } 2009\end{array}$ \\
\hline $\begin{array}{l}\text { Ottawa } \\
\text { (Canada) }\end{array}$ & 934240 & 101 & 38.1 & 33.5 & 14.8 & 41.7 & - & - & Rasmussen et al., 2001 \\
\hline $\begin{array}{l}\text { Tehran } \\
\text { (Iran) }\end{array}$ & 8293140 & 370,0 & 182,9 & 110,3 & - & - & - & - & Taghavi et al., 2019 \\
\hline $\begin{array}{l}\text { Tehran } \\
\text { (Iran) }\end{array}$ & 8100000 & 694,8 & 286,1 & 81,3 & 45,1 & 38,2 & - & - & Kamani et al., 2017 \\
\hline $\begin{array}{l}\text { Eslamshahr } \\
\text { (Iran) }\end{array}$ & 357171 & 573,0 & 239,0 & 71,3 & 42,4 & 35,1 & - & - & Kamani et al., 2018 \\
\hline $\begin{array}{l}\text { Lublin } \\
\text { (Poland) }\end{array}$ & 341975 & 201.8 & 65.7 & 23.3 & 26.8 & 52.8 & - & - & Kiebała et al., 2015 \\
\hline $\begin{array}{l}\text { Warsaw } \\
\text { (Poland) }\end{array}$ & 1735000 & 63.60 & 30.60 & 33.85 & 10.31 & - & 134.10 & 600 & Kozanecka et al., 2003 \\
\hline $\begin{array}{l}\text { Białystok } \\
\text { (Poland) }\end{array}$ & 294153 & 68.99 & 16.37 & 11.42 & 5.20 & 9.12 & 68.62 & 2335 & Present study, 2018 \\
\hline
\end{tabular}

Table 3. Values of geochemical index ( $\left.\mathrm{I}_{\text {geo }}\right)$

\begin{tabular}{|c|c|c|c|c|c|c|c|c|}
\hline \multirow{5}{*}{$\begin{array}{l}\text { Road } \\
\text { dust } \\
\text { in Bialystok }\end{array}$} & \multirow{2}{*}{ Statistic data } & \multicolumn{7}{|c|}{$\mathrm{I}_{\mathrm{geo}}$} \\
\hline & & $\mathrm{Zn}$ & $\mathrm{Cu}$ & $\mathrm{Pb}$ & $\mathrm{Ni}$ & $\mathrm{Cr}$ & $\mathrm{Mn}$ & $\mathrm{Fe}$ \\
\hline & Min & -2.73 & -5.16 & -4.60 & -9.73 & -5.07 & -7.56 & -7.46 \\
\hline & Max & 0.27 & 0.11 & 1.38 & -2.89 & -2.65 & -2.72 & 0.56 \\
\hline & Mean & -1.47 & -2.74 & -2.43 & -4.68 & -4.09 & -4.48 & -2.34 \\
\hline
\end{tabular}


congestion are higher than in other areas. This observation is consistent with the analysis of metallic content and suggests that high traffic density and high population density affect the distribution of metals in road dust in Białystok.

\section{Spatial Distribution of Metals in Road Dust}

The study of spatial metal distribution in road dust on city roads is helpful in identifying places with increased metallic content as well as in assessing potential sources of pollution. Obtained maps for $\mathrm{Zn}, \mathrm{Cu}, \mathrm{Pb}, \mathrm{Ni}, \mathrm{Cr}, \mathrm{Mn}$ and $\mathrm{Fe}$ content in road dust samples from the city of Białystok are shown in Fig. 2.

The highest metallic content in the dust occurred in the north-western part of the city, where there are roads with heavy traffic connecting Białystok with the capital of Poland, Warsaw. This was particularly evident in the case of $\mathrm{Zn}, \mathrm{Mn}, \mathrm{Pb}$ (Figs. 2(a), 2(f) and 2(c)). Larger metallic content also occurred in the center of Białystok, on roads leading to border crossings with the Republic of Belarus and Lithuania and near intersections, roundabouts with the highest traffic intensity, observed for $\mathrm{Cu}, \mathrm{Fe}, \mathrm{Ni}$ and $\mathrm{Cr}$ (Figs. 2(b), 2(g), 2(d) and 2(e)). Similar findings were also presented by Duong and Lee (2011), who showed that the content of heavy metals in road dust varies greatly depending on traffic volume; road functions, e.g., roundabouts and highways; and traffic lights. The wind direction plays a major role in the transport of dust, and thus in determining the spatial distribution of metals. In the case of Białystok, the prevailing wind blows from the west and the south-west, transporting road dust to the east and northeast (Figs. 1 and 2). Based on the wind map and metal spatial distributions, no potential hazards from other sources of pollution for the environment of Białystok were found.

\section{Identification of Pollution Sources Applying Statistical Analyses}

Statistical analyses were started from the Shapiro-Wilk normality test (Table 1). The test results indicate that the content of all metals in the area with high congestion do not have a normal distribution. At the same time, high values of the coefficient of variation in relation to some metals are visible ( $\mathrm{Pb}: 133 \%$; $\mathrm{Fe}: 95 \%$; $\mathrm{Cu}: 91 \%$; $\mathrm{Zn}: 58 \%)$. $\mathrm{Cr}$ and $\mathrm{Mn}$ content in the area with low congestion already show a normal distribution. The coefficient of variability for metals in these places ranged from $84 \%(\mathrm{Cu})$ to $18 \%(\mathrm{Mn})$. In potentially unpolluted area (parks and green areas), normal distributions have been shown in the case of $\mathrm{Zn}, \mathrm{Pb}, \mathrm{Cr}, \mathrm{Mn}$ and $\mathrm{Fe}$. Metal variability coefficients were in a similar range as in the area with low congestion, from $80 \%(\mathrm{Cu})$ to $24 \%$ (Cr). Lu et al. (2010) showed that the greater the coefficient of variability expressed in percentage, the more analyzed data deviate from the normal distribution.

Smaller variations in the amount of metals in the dust were visible in low-congestion and potentially unpolluted areas. The largest coefficient of variation was for $\mathrm{Pb}(133 \%)$ in areas with the highest congestion. Currently, research

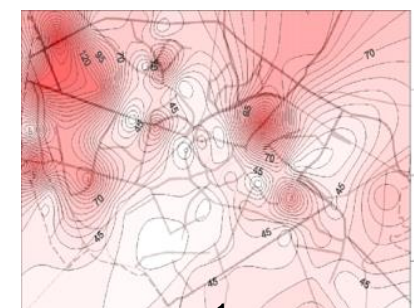

a) $\mathrm{Zn}\left(\mathbf{m g} \times \mathbf{k g}^{-1}\right)$

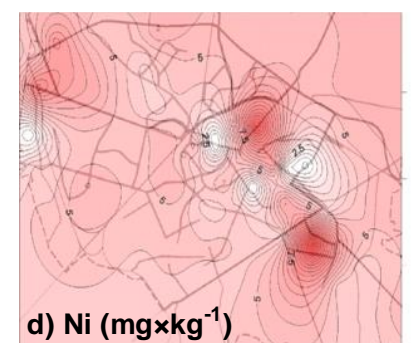

d) $\mathrm{Ni}\left(\mathrm{mg} \times \mathrm{kg}^{-1}\right)$
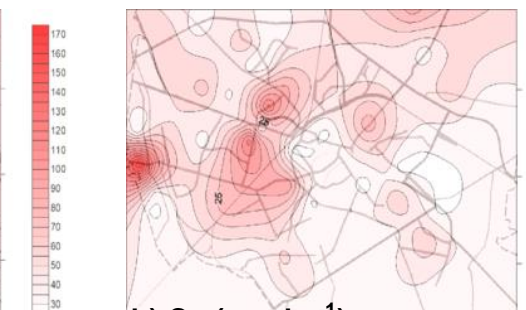

b) $\mathrm{Cu}\left(\mathrm{mg} \times \mathrm{kg}^{-1}\right)$

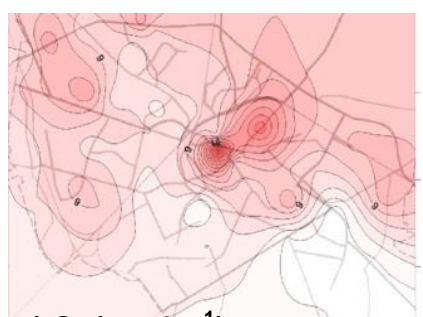

e) $\operatorname{Cr}\left(\mathrm{mg} \times \mathrm{kg}^{-1}\right)$
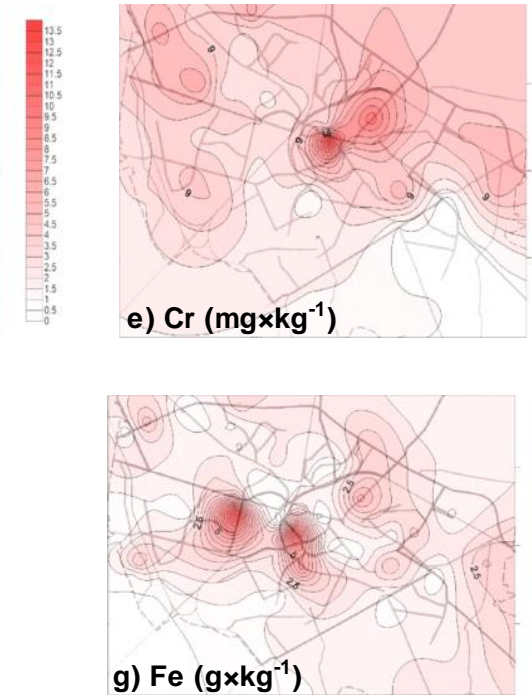
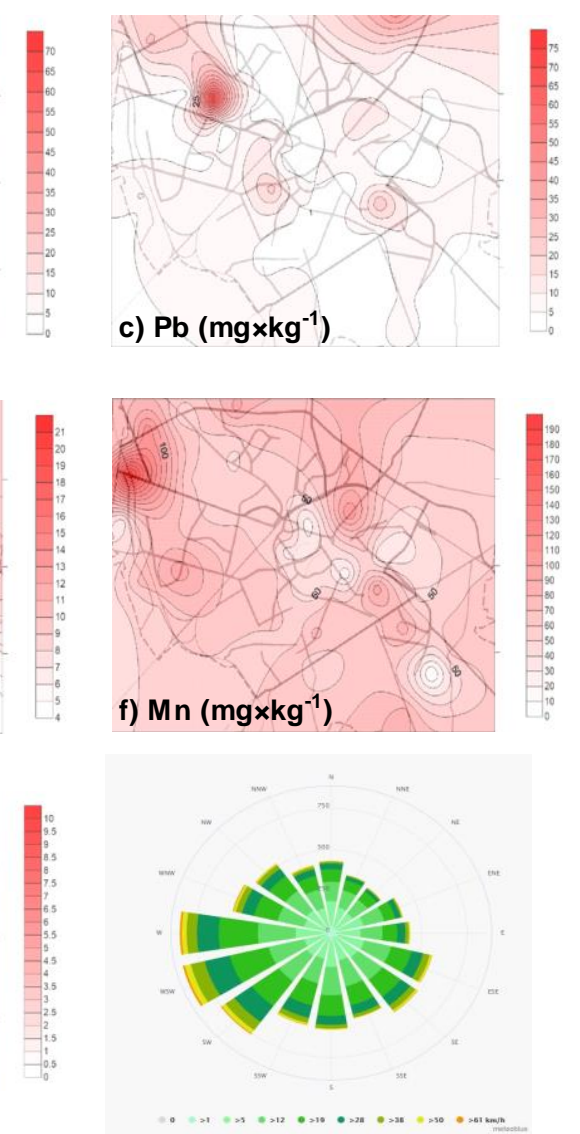

Fig. 2. Spatial distribution of heavy metals in road dust in Bialystok. 
carried out by Apeagyei et al. (2011) shows that the treads of tires contained very large amounts of $\mathrm{Zn}$ (median: 17,720 $\mathrm{mg} \mathrm{kg}^{-1}$ ) and the material of brake pads contained the largest amounts of Fe (median: 102,080 $\mathrm{mg} \mathrm{kg}^{-1}$ ). Quantitatively, these were the highest content compared to other metals tested. It turned out that $\mathrm{Zn}$ content in the tires was 15 times greater than in the brake pads. Therefore, $\mathrm{Zn}$ was considered an indicator of tire wear and $\mathrm{Fe}$ an indicator of brake wear. Pearson correlations between the investigated metals in street dust are presented in Table 4.

An analysis of correlation coefficients was carried out to assess the relationship between the analyzed elements in road dust. In areas with the largest congestion, $\mathrm{Zn}$ was significantly correlated with $\mathrm{Cu}, \mathrm{Pb}, \mathrm{Ni}$ and $\mathrm{Cr}$, in areas with low congestion, with $\mathrm{Ni}$ and $\mathrm{Cr}$. These correlations testify to the common source of metal impurities associated with intensive car traffic, in particular with frequent braking and acceleration. In Białystok, in high-congestion areas, high traffic volumes of up to 30,720 vehicles per day were observed. In other areas, there is a lower number of $\mathrm{Zn}$ correlations or none at all, which is also associated with traffic volumes from 2,640 to 18,000 vehicles per day. However, in areas not potentially contaminated, no significant $\mathrm{Zn}$ correlation with other metals occurred. From research by Lu et al. (2009), it is evident that $\mathrm{Mn}$ is one of the fuel components and their combustion processes are one of the emission factors of this metal. This was confirmed by studies carried out in areas with high congestion, which showed that Mn was correlated with $\mathrm{Zn}, \mathrm{Cu}, \mathrm{Pb}$ and $\mathrm{Ni}$. On the other hand, in the case described here, Mn can also have a natural origin, which confirms the fact that its content did not exceed the geochemical background of value. Studies carried out by Rasmussen et al. (2001) and Yang et al. (2010) indicate the natural origin of $\mathrm{Mn}$ is associated with the parent rock. As a result of the conducted analyses, no significant correlation of metals with $\mathrm{Fe}$ was found in areas with high congestion. In areas with low congestion, $\mathrm{Fe}$ is correlated with $\mathrm{Mn}$ and $\mathrm{Ni}$, as well as with $\mathrm{Mn}, \mathrm{Ni}, \mathrm{Cu}$ and $\mathrm{Zn}$ in potentially unpolluted areas. It should be noted that some of the investigated metals are constituents of soils (Chow et al., 2003), especially urban ones, which are less modified in potentially unpolluted areas. The lack or small number of metal correlations in areas with low congestion and in potentially unpolluted areas may indicate a variety of sources (Pan et al., 2017). Strong correlation of Fe with $\mathrm{Mn}(\mathrm{r}=0.85)$ in potentially unpolluted areas may indicate the natural origin of these elements. The soils and the parent material from partially forested areas are characterized by the co-occurrence of Fe and Mn, as indicated by many studies in Poland and abroad. Correlations between $\mathrm{Zn}$, and $\mathrm{Cu}, \mathrm{Pb}, \mathrm{Fe}, \mathrm{Mn}$ vs. other metals suggest that these metals have two common sources, namely motor vehicles and industrial activities (Yongming et al., 2006; Kabadayi and Cesur, 2010). As reported by Manno et al. (2006), the highest amounts of $\mathrm{Zn}, \mathrm{Ni}$ and $\mathrm{Cu}$ occur in urban and industrial areas. According to Amato et al. (2011), the origin of $\mathrm{Zn}, \mathrm{Ni}, \mathrm{Cu}$ and $\mathrm{Cr}$ is related to the wear of tires and brakes, while the origin of Fe can be related to the emission of exhaust gases and wear of brakes. As shown by Ukah et al. (2019), there were $\mathrm{Zn}$ correlations with $\mathrm{Cu}$, $\mathrm{Cr}, \mathrm{Mn}$ in metal-contaminated groundwater. The study used cluster analysis in the Ward version based on the measurement of the distance of Euclidean similarities (Lu et al., 2010).

Table 4. Pearson's correlations matrix for the metal concentrations. Correlation is significant at the 0.05 level.

\begin{tabular}{|c|c|c|c|c|c|c|c|}
\hline & $\mathrm{Fe}$ & Mn & $\mathrm{Zn}$ & $\mathrm{Cu}$ & $\mathrm{Pb}$ & $\mathrm{Ni}$ & $\mathrm{Cr}$ \\
\hline \multicolumn{8}{|c|}{ (a) Large congestion } \\
\hline $\mathrm{Fe}$ & 1 & & & & & & \\
\hline Mn & 0.25 & 1 & & & & & \\
\hline $\mathrm{Zn}$ & 0.07 & 0.71 & 1 & & & & \\
\hline $\mathrm{Cu}$ & 0.19 & 0.55 & 0.58 & 1 & & & \\
\hline $\mathrm{Pb}$ & 0.08 & 0.52 & 0.53 & 0.59 & 1 & & \\
\hline $\mathrm{Ni}$ & 0.17 & 0.82 & 0.64 & 0.47 & 0.54 & 1 & \\
\hline $\mathrm{Cr}$ & 0,1 & 0.29 & 0.35 & -0.02 & 0.02 & 0.39 & 1 \\
\hline \multicolumn{8}{|c|}{ (b) Small congestion } \\
\hline $\mathrm{Fe}$ & 1 & & & & & & \\
\hline Mn & 0.4 & 1 & & & & & \\
\hline $\mathrm{Zn}$ & 0,29 & 0.17 & 1 & & & & \\
\hline $\mathrm{Cu}$ & 0.00 & 0.31 & 0.21 & 1 & & & \\
\hline $\mathrm{Pb}$ & 0.18 & 0.24 & 0.26 & 0.34 & 1 & & \\
\hline $\mathrm{Ni}$ & 0.45 & 0.28 & 0.43 & 0.44 & 0.51 & 1 & \\
\hline $\mathrm{Cr}$ & 0.36 & -0.1 & 0.61 & 0.27 & 0.39 & 0.52 & 1 \\
\hline \multicolumn{8}{|c|}{ (c) Parks and green areas } \\
\hline $\mathrm{Fe}$ & 1 & & & & & & \\
\hline Mn & 0.85 & 1 & & & & & \\
\hline $\mathrm{Zn}$ & 0.32 & 0.35 & 1 & & & & \\
\hline $\mathrm{Cu}$ & 0.55 & 0.52 & 0.22 & 1 & & & \\
\hline $\mathrm{Pb}$ & 0.27 & 0.2 & 0.05 & 0.37 & 1 & & \\
\hline $\mathrm{Ni}$ & 0.35 & 0.32 & -0.01 & 0.55 & 0.84 & 1 & \\
\hline $\mathrm{Cr}$ & -0.29 & -0.19 & -0.22 & 0.18 & 0.24 & 0.46 & 1 \\
\hline
\end{tabular}


Three groups are distinguished in Fig. 3: Group 1 (Fe), Group 2 ( $\mathrm{Mn}$ and $\mathrm{Zn}$ ), and Group $3(\mathrm{Cu}, \mathrm{Pb}, \mathrm{Ni}$ and $\mathrm{Cr}$ ). The metal classification was predominantly dependent on their content, which for each class had its own range. In Group 1, the highest Fe content was obtained and in Group 3 the lowest $\mathrm{Cu}, \mathrm{Pb}, \mathrm{Ni}$ and $\mathrm{Cr}$ content were distinguished.

The PCA allowed us to identify potential sources of pollution (Table 5).

In Table 5(a) relating to the area with large congestion, there are two factors explaining $44 \%$ of the variability in total. Factor 1 is the most important, because it explains most variability (30\%) and is correlated with $\mathrm{Mn}, \mathrm{Zn}$ and $\mathrm{Ni}$. The area with large congestion is characterized by high car traffic. Possible sources of these metals are primarily the surrounding soil, as well as the result of wear of vehicle parts, especially tires. Intensive traffic, intersections and traffic lights in the test area require drivers to frequently use the brakes and then accelerate to continue driving, which consumes tires, brake pads and brake linings. According to Adachia and Tainoshob (2004) as well as Apeagyei et al. (2011), severe wear of tires and brake pads can cause a high content of heavy metals such as Fe, $\mathrm{Zn}$ and Ni. The source of
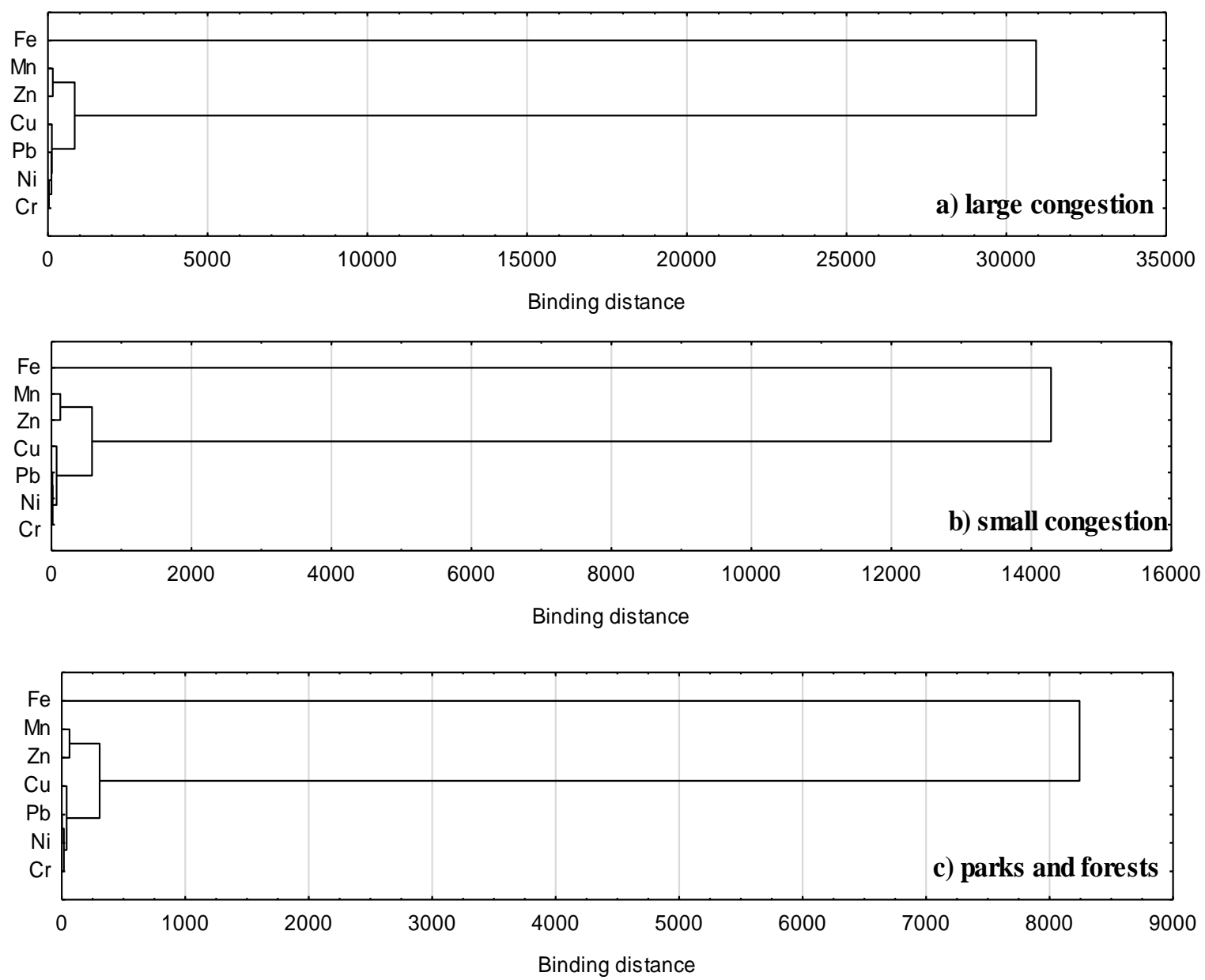

Fig. 3. Hierarchical dendrograms for heavy metals in dust obtained by Ward's hierarchical clustering method.

Table 5. The rotated component matrix for data of metals in street dusts of Bialystok $(n=69)$. Principal factors $>0.7$ are selected in each column.

\begin{tabular}{|c|c|c|c|c|c|c|}
\hline \multirow{2}{*}{ Variables } & \multicolumn{2}{|c|}{ (a) Large congestion } & \multicolumn{2}{|c|}{ (b) Small congestion } & \multicolumn{2}{|c|}{ (c) Parks and gren areas } \\
\hline & Factor 1 & Factor 2 & Factor 1 & Factor 2 & Factor 1 & Factor 2 \\
\hline $\mathrm{Fe}$ & -0.07 & 0.56 & 0.55 & 007 & 0.83 & -0.17 \\
\hline Mn & 0.87 & 0.02 & 0.80 & -0.14 & 0.81 & -0.23 \\
\hline $\mathrm{Zn}$ & 0.86 & 0.02 & 0.23 & 0.72 & 0.50 & 0.11 \\
\hline $\mathrm{Cu}$ & 0.38 & 0.48 & 0.07 & 0.41 & 0.44 & 0.69 \\
\hline $\mathrm{Pb}$ & 0.29 & -0.03 & 0.53 & 0.18 & 0.83 & 0.21 \\
\hline $\mathrm{Ni}$ & 0.78 & 0.31 & 0.79 & 0.40 & 0.91 & 0.24 \\
\hline $\mathrm{Cr}$ & 0.23 & -0.59 & 0.11 & 0.83 & -0.05 & 0.47 \\
\hline$\%$ of variance & 30 & 14 & 32 & 19 & 41 & 23 \\
\hline
\end{tabular}


$\mathrm{Mn}$ in this area may be fuel combustion processes. Factor 2 is difficult to interpret, because it does not show any significant correlations with metals.

The PCA for the low-congestion area (Table 5(b)) showed 2 explanatory factors for a total of $51 \%$ variation. The first factor explaining $32 \%$ of the variability is correlated with $\mathrm{Mn}$ and $\mathrm{Ni}$ and the second explains $19 \%$ of the variability with $\mathrm{Zn}$ and $\mathrm{Cr}$. Factor 2 is more important because of $\mathrm{Zn}$ and $\mathrm{Cr}$ that are found in road dust as a result of abrasion of car tires and abrasion of paints and varnishes covering parts of vehicles. The level of explained variability of the second factor is smaller than Factor 1 in PCA for areas with high congestion. In association with the above, the conducted PCA confirmed lower emission of metals from car traffic in areas with lower congestion (in particular regarding $\mathrm{Zn}$ ). On the other hand, the first factor correlated with $\mathrm{Mn}$ and $\mathrm{Ni}$ may be related to the local parent material occurring at the sampling sites, for example urban soils. Considering the metals that are correlated with Factor $1(\mathrm{Mn}$ and $\mathrm{Ni})$ and Factor 2 ( $\mathrm{Zn}$ and $\mathrm{Cr}$ ), one can put forward the thesis about the fuel combustion processes prevailing over the consumption of tires, e.g., related to their abrasion, in this area. In the area with low congestion, there is less frequency of braking and restarting of vehicles, which is associated with $\mathrm{Zn}$ emission in the course of tire wear on road surfaces. The PCA calculations for uncontaminated areas (Table 5(c)) showed 2 factors. The first factor explaining $41 \%$ of the variability is correlated with $\mathrm{Fe}, \mathrm{Mn}, \mathrm{Pb}$ and $\mathrm{Ni}$ and the other one did not show any significant connections. Considering the type of areas in this case, one can point to the partly natural origin, especially $\mathrm{Fe}$ and $\mathrm{Mn}$. On the other hand, the presence of $\mathrm{Pb}$ can be the result of adding it to gasoline. The $\mathrm{Pb}$ content in urban road dust still reflects a significant degree of historical pollution and a long period of half-life in soils surrounding urban roads (Rajaram et al., 2014). Pearson's CA, cluster analysis, and PCA indicated that vehicles, industry, coal combustion, oil fuel, dust, and biomass burning were probably the main sources of PM elements and metals in Zhengzhou, China (Jiang et al., 2019). The PCA identified the following dust sources: high car traffic, surrounding soil, abrasion of brake pads, brake linings, car tires, paints and varnishes covering parts of vehicles, and fuel combustion processes.

\section{CONCLUSIONS}

We used multidimensional statistical techniques in combination with elemental analysis to identify the sources of the metallic content found in samples of road dust from Białystok. $\mathrm{Fe}, \mathrm{Zn}, \mathrm{Mn}$, and $\mathrm{Cu}$ were the most abundant elements. Additionally, the average concentrations of $\mathrm{Zn}$ and $\mathrm{Cu}$, unlike those of the other analyzed metals, exceeded the geochemical background levels for Polish soil, indicating significant anthropogenic sources for these two constituents. We mapped the metallic concentrations in the samples to evaluate the spatial distribution of these elements and discovered that the highest values, which were particularly prominent for $\mathrm{Zn}, \mathrm{Mn}$, and $\mathrm{Pb}$, occurred in the north-western part of the city, where roads with heavy traffic connect
Białystok to Warsaw, the capital of Poland. Higher concentrations for $\mathrm{Cu}, \mathrm{Fe}, \mathrm{Ni}$, and $\mathrm{Cr}$ were also observed in the center of Białystok and near crossroads displaying the maximum traffic volume and high congestion.

The highest average $I_{g e o}$ value was calculated for $\mathrm{Zn}$, followed by $\mathrm{Fe}, \mathrm{Pb}, \mathrm{Cu}, \mathrm{Cr}, \mathrm{Mn}$, and $\mathrm{Ni}$. Our results indicate that the road dust is generally uncontaminated in Białystok, which, notably, is located in the region known as the "Green Lungs" of Poland, where $32 \%$ of the area is green. However, locations with heavy traffic congestion exhibited higher $\mathrm{I}_{\text {geo }}$ values than the other functional areas we sampled, which is consistent with our elemental analysis and suggests that high traffic and population density affect the distribution of metals in this city's road dust.

Pearson's correlation coefficients link the concentrations of $\mathrm{Mn}$ and $\mathrm{Zn}$ to intensive vehicular traffic in the most congested areas. The heavy metals were grouped via cluster analysis according to their concentrations: Cluster 1 contained $\mathrm{Fe}$; Cluster 2, $\mathrm{Mn}$ and $\mathrm{Zn}$; and Cluster 3, $\mathrm{Cu}, \mathrm{Pb}, \mathrm{Ni}$, and $\mathrm{Cr}$. The PCA showed a correlation between Factor 1, which was associated with vehicle operation (the wear on tires, corrosion of vehicular bodies, destruction of road surfaces, and abrasion of brake pads and discs), and $\mathrm{Zn}, \mathrm{Ni}$, and $\mathrm{Mn}$. The spatial distributions of these metals were very similar and characterized by significant variability in areas with high congestion. The PCA also confirmed lower metallic emissions, particularly of $\mathrm{Zn}$, which is related to tire wear, from vehicular traffic in less congested areas, where the vehicles infrequently stopped and restarted. Furthermore, the $\mathrm{Fe}$ and $\mathrm{Mn}$ measured in the road dust of potentially unpolluted areas arose from similar, natural sources. However, $\mathrm{Pb}$ originating from historical pollution was detected even in these theoretically uncontaminated areas.

\section{ACKNOWLEDGEMENTS}

The research was carried out as part of Research Project No. WZ/WBiIŚ/8/2019 at Białystok University of Technology and financed from a subsidy provided by the Ministry of Science and Higher Education.

\section{REFERENCES}

Acosta, J.A., Faz, A., Kalbitz, K., Jansen, B. and MartinezMartinez, S. (2014). Partitioning of heavy metals over different chemical fraction in street dust of Murcia (Spain) as a basis for risk assessment. J. Geochem. Explor. 144: 298-305. https://doi.org/10.1016/j.gexplo.2014.02.004

Adachia, K. and Tainoshob, Y. (2004). Characterization of heavy metal particles embedded in tire dust. Environ. Int. 30: 100-1017. https://doi.org/10.1016/j.envint.2004.04.004

Adamiec, E., Jarosz-Krzemińska, E. and Wieszała, R. (2016). Heavy metals from non-exhaust vehicle emissions in urban and motorway road dusts. Environ. Monit. Assess. 188: 369. https://doi.org/10.1007/s10661-016-5377-1

Adamiec, E. (2017). Traffic-related metals as sources of urban environment pollution: A case study of Kraków, Poland. WIT Trans. Ecol. Environ. 214: 81-89. https://doi.org/10.2495/ECO170081 
Alsbou, E.M.E. and Al-Khashman, O.A. (2018). Heavy metal concentrations in roadside soil and street dust from Petra region, Jordan. Environ. Monit. Assess. 190: 48. https://doi.org/10.1007/s10661-017-6409-1

Amato, F., Pandolfi, M., Moreno, T., Furger, M., Pey, J., Alastuey, A., Bukowiecki, N., Prevot A.S.H., Baltensperger, U. and Querol, X. (2011). Sources and variability of inhalable road dust particles in three European cities. Atmos. Environ. 45: 6777-6787. https://doi.org/10.1016/ j.atmosenv.2011.06.003

Amato, F., Cassee, F.R., Van der Gon, H.A.C.D., Gehrig, R., Gustafsson, M., Hafner, W., Harrison, R.M., Jozwicka, M., Kelly, F.J., Moreno, T., Prevot, A.S.H., Schaap, M., Sunye, J. and Querol, X. (2014). Urban air quality: The challenge of traffic non-exhaust emissions. J. Hazard. Mater. 275: 31-36. https://doi.org/10.1016/j.jhazmat.201 4.04.053

Apeagyei, E., Bank, M.S. and Spengler, J.D. (2011). Distribution of heavy metals in road dust along an urbanrural gradient in Massachusetts. Atmos. Environ. 45: 2310 2323. https://doi.org/10.1016/j.atmosenv.2010.11.015

Bardelli, F., Cattaruzza, E., Gonella, F., Rampazzo, G. and Valotto, G. (2011). Characterization of road dust collected in Traforo del San Bernardo highway tunnel: Fe and Mn speciation. Atmos. Environ. 45: 6459-6468. https://doi.org/10.1016/j.atmosenv.2011.07.035

Bartkowiak, A., Dąbkowska-Naskręt, H., Lemanowicz, J. and Siwik-Ziomek, A. (2017). Assessment of physicochemical and biochemical factors of urban street dust. Environ. Prot. Eng. 43: 155-164. https://doi.org/10.37190/EPE17 0310

Bhattacharya, T., Chakraborty, S., Tuteja, D. and Patel, M. (2013). Zinc and chromium load in road dust, suspended particulate matter and foliar dust deposits of Anand City, Gujarat. Open J. Met. 3: 42-50. https://doi.org/10.4236/o jmetal.2013.32A1006

Bourliva, A., Christophoridis, C., Papadopoulou, L., Giouri, K., Papadopoulos, A., Mitsika, E. and Fytianos, K. (2017). Characterization, heavy metal content and health risk assessment of urban road dusts from the historic center of the city of Thessaloniki, Greece. Environ. Geochem. Health 39: 611-634. https://doi.org/10.1007/s 10653-016-9836-y

Carrero, J.A., Goienaga, N., Olivares, M., Martinez-Arkarazo, I. and Arana, G. (2012). Raman spectroscopy assisted with XRF and chemical simulation to assess the synergic impacts of guardrails and traffic pollutants on urban soils. J. Raman Spectrosc. 43: 1498-1503. https://doi.org/10.10 02/jrs.4089

Central Statistical Office (2018). Statistical yearbook of the Republic of Poland 2018, Statistics Poland, Warsaw.

Charlesworth, S., Everett, M., McCarthy, R., Ordóñez, A. an De Miguel, E. (2003). A comparative study of heavy metal concentration and distribution in deposited street dusts in a large and a small urban area: Birmingham and Coventry, West Midlands, UK. Environ. Int. 29: 563-573. https://doi.org/10.1016/S0160-4120(03)00015-1

Chen, J.Q., Wang, Z.X., Wu, X., Zhu, J.J. and Zhou, W.B. (2011). Source and hazard identification of heavy metals in soils of Changsha based on TIN model and direct exposure method. Trans. Nonferrous Met. Soc. China 21: 642-651. https://doi.org/10.1016/S1003-6326(11)60761-9 Chow, J.C., Watson, J.G., Ashbaugh, L.L. and Magliano, K.L. (2003). Similarities and differences in $\mathrm{PM}_{10}$ chemical source profiles for geological dust from the San Joaquin Valley, California. Atmos. Environ. 37: 13171340. https://doi.org/10.1016/S1352-2310(02)01021-X

Christoforidis, A. and Stamatis, N. (2009). Heavy metal contamination in street dust and roadside soil along the major national road in Kavala's region, Greece. Geoderma 151: 257-263. https://doi.org/10.1016/j.geoderma.2009.0 4.016

Czarnowska, K. (1996). Total heavy metal content in parent rocks as geochemical background of soils, Soil Science. LX VII: 43-50. (in polish)

Czubaszek, R. and Bartoszuk, K. (2011). Content of selected heavy metals in soils in accordance with its distance from the street and land use. Scientific books of the Bialystok University of Technology, Environmental Engineering. 2: 27-34. (in polish)

De Miguel, D., F. Llamas, J., Chacón, E., Berg, T., Larssen, S., Røyset, O. and Vadset, M. (1997). Origin and patterns of distribution of trace elements in street dust: Unleaded petrol and urban lead. Atmos. Environ. 31: 2733-2740. https://doi.org/10.1016/S1352-2310(97)00101-5

Duong, T.T.T. and Lee, B.K. (2011). Determining contamination level of heavy metals in road dust from busy traffic areas with different characteristics. $J$. Environ. Manage. 92: 554-562. https://doi.org/10.1016/ j.jenvman.2010.09.010

El-Sergany MM, El-Sharkawy MF. (2011). Heavy metal contamination of airborne dust in the environment of two main cities in the Eastern Province of Saudi Arabia. JKAU: Met. Env. Arid Land Agric. Sci. 22: 135-148. https://doi.org/10.4197/Met. 22-1.10

European Environment Agency (EEA) (2016). Air quality in Europe - 2016 report. https://www.eea.europa.eu/pub lications/air-quality-in-europe-2016

Ferreira-Baptista, F. And De Miguel, E. (2005). Geochemistry and risk assessment of street dust in Luanda, Angola: A tropical urban environment. Atmos. Environ. 39: 4501-4512. https://doi.org/10.1016/j.atmosenv.2005. 03.026

Gawade, A., Deshmukh, P., Shivankar, V. and Gavali, L. (2016). Analysis of Roadside Dust for Heavy Metal Pollutants in Navi Mumbai. Int. J. Eng. Technol. Manage. Appl. Sci. 4: 2349-4476.

Greening, T. (2011). Quantifying the impacts of vehiclegenerated dust: A comprehensive approach. The International Bank for Reconstruction and Development/ The World Bank, USA. https://doi.org/10.1596/27891

Han, N.M.M., Latif, M.T., Othman, M., Dominick, D., Mohamad, N., Juahir, H. and Tahir, N.M. (2014). Composition of selected heavy metals in road dust from Kuala Lumpur city centre. Environ. Earth Sci. 72: 849859. https://doi.org/10.1007/s12665-013-3008-5

Jiang, N., Liu, X., Wang, S., Yu, X., Yin, S., Duan, S., Wang, S., Zhang, R. and Li, S. (2019). Pollution 
Characterization, source identification, and health risks of atmospheric-particle-bound heavy metals in $\mathrm{PM}_{10}$ and $\mathrm{PM}_{2.5}$ at multiple sites in an emerging megacity in the central region of China. Aerosol Air Qual. Res. 19: 247271. https://doi.org/10.4209/aaqr.2018.07.0275

Kabadayi, F. and Cesur, H. (2010). Determination of $\mathrm{Cu}, \mathrm{Pb}$, $\mathrm{Zn}, \mathrm{Ni}, \mathrm{Co}, \mathrm{Cd}$ and $\mathrm{Mn}$ in road dusts of Samsun City. Environ. Monit. Assess. 168: 241-253. https://doi.org/10. 1007/s10661-009-1108-1

Kamani, H., Mahvi, A.H., Seyedsalehi, M., Jaafari, J., Hoseini, M., Safari, G.H., Dalvand, A., Aslani, H., Mirzaei, N. and Ashrafi, S.D. (2017). Contamination and ecological risk assessment of heavy metals in street dust of Tehran, Iran. Int. J. Environ. Sci. Technol. 14: 26752682. https://doi.org/10.1007/s13762-017-1327-x

Kamani, H., Mirzaei, N., Ghaderpoori, M., Bazrafshan, E., Rezaei, S. and Mahvi, A.H. (2018). Concentration and ecological risk of heavy metal in street dusts of Eslamshahr, Iran. Hum. Ecol. Risk Assess. 24: 961-970. https://doi.org/10.1080/10807039.2017.1403282

Khairy, M.A., Barakat, A.O., Mostafa, A.R. and Wade, T.L. (2011). Multielement determination by flame atomic absorption of road dust samples in Delta Region, Egypt. Microchem. J. 97: 234-242. https://doi.org/10.1016/j.mi croc.2010.09.012

Kiebała, A., Kozieł, M. and Zgłobicki, W. (2015). Cr, Cu, $\mathrm{Ni}, \mathrm{Pb}$ and $\mathrm{Zn}$ in road dust in the Lublin area. Eng. Environ. Prot. 18: 299-310. (in Polish).

Kozanecka, T., Czarnowska, K. and Jaworska, A. (2003). Content of heavy metals in road coarse dust of Warsaw environs. Soil Sci. Annu. 54: 73-78. (in Polish)

Li, F., Zhang, J., Huang, J., Huang, D., Yang, J., Song, Y. and Zeng, G. (2016). Heavy metals in road dust from Xiandao District, Changsha City, China: characteristics, health risk assessment, and integrated source identification. Environ. Sci. Pollut. Res. 23: 1310013113. https://doi.org/10.1007/s11356-016-6458-y

Lu, X., Wang, L., Lei, K., Huang, J. and Zhai, Y. (2009). Contamination assessment of copper, lead, zinc, manganese and nickel in street dust of Baoji, NW China. J. Hazard. Mater. 161: 1058-1062. https://doi.org/10.10 16/j.jhazmat.2008.04.052

Lu, X., Wang, L., Li, L.Y., Lei, K., Huang, L. and Kang, D. (2010). Multivariate statistical analysis of heavy metals in street dust of Baoji NW China. J. Hazard. Mater. 173: 744-749. https://doi.org/10.1016/j.jhazmat.2009.09.001

Manno, E., Varrica, D. and Dongarra, G. (2006). Metal distribution in road dust samples collected in an urban area close to a petrochemical plant at Gela, Sicily. Atmos. Environ. 40: 5929-5941. https://doi.org/10.1016/j.atmos env.2006.05.020

Martin, S. and Griswold, W. (2009). Human health effects of heavy metals. Environ. Sci. Technol. Briefs Citizens 15: $1-6$.

Meister, K., Johansson, C. and Forsberg, B. (2012). Estimated short-term effects of coarse particles on daily mortality in Stockholm, Sweden. Environ. Health Perspect. 120: 431-436. https://doi.org/10.1289/ehp.1103995

Müller, G. (1969). Index of geo-accumulation in sediments of the Rhine River. Geol. J. 2: 108-118.

Municipal Office in Białystok (2010). The Biatystok City Development Strategy for years 2011-2020 Plus. Annex to Resolution No. LVIII/777/10 of the City Council of Bialystok of 13 September 2010. https://www.bialystok.p 1/pl/dla_biznesu/rozwoj_miasta/strategia-rozwoju-miastabialego.html

Ozaki, H., Watanabe, I. and Kuno, K. (2004). Investigation of the heavy metal sources in relation to automobiles. Water Air Soil Pollut. 157: 209-223. https://doi.org/10.1 023/B:WATE.0000038897.63818.f7

Pan, H., Lu, X. and Lei, K. (2017). A comprehensive analysis of heavy metals in urban road dust of Xi'an, China: Contamination, source apportionment and spatial distribution. Sci. Total Environ. 609: 1361-1369. https://doi.org/10.1016/j.scitotenv.2017.08.004

Qiao, Q., Zhang, C., Huang, B. and Piper, J.D.A. (2011). Evaluating the environmental quality impact of the 2008 Beijing Olympic Games: Magnetic monitoring of street dust in Beijing Olympic, Park. Geophys. J. Int. 187: 12221236. https://doi.org/10.1111/j.1365-246X.2011.05195.x

Rajaram, B.S., Suryawanshi, P.V., Bhanarkar, A.D. and Rao C.V.C. (2014). Heavy metals contamination in road dust in Delhi city, India. Environ. Earth Sci. 72: 3929-3938. https://doi.org/10.1007/s12665-014-3281-y

Rasmussen, P.E., Subramanian, K.S. and Jessiman. B.J. (2001). A multi-element profile of housedust in relation to exterior dust and soils in the city of Ottawa, Canada. Sci. Total Environ. 267: 125-140. https://doi.org/10.1016/ S0048-9697(00)00775-0

Rexeis, M. and Hausberger, S. (2009). Trend of vehicle emission levels until 2020-Prognosis based on current vehicle measurements and future emission legislation. Atmos. Environ. 43: 4689-4698. https://doi.org/10.1016/ j.atmosenv.2008.09.034

Schauer, J.J., Lough, G.C., Shafer, M.M., Christensen, W.F., Arndt, M.F., DeMinter, J.T. and Park, J.S. (2006). Characterization of metals emitted from motor vehicles. Research Report 133. Health Effects Institute, Boston MA. pp.77-88.

Skorbiłowicz, E., Dzienis, L. and Skorbiłowicz, M. (2001). Heavy metals in the surface layer of soil in Białystok. Scientific Papers of the Białystok University of Technology. Environmental Engineering. 14: 97-107. (in Polish)

Smolders, E. and Degryse, F. (2002). Fate and effect of zinc from tire debris in soil. Environ. Sci. Technol. 36: 37063710. https://doi.org/10.1021/es025567p

Suryawanshi, P.V., Rajaram, B.S., Bhanarkar, A.D. and Chalapatirao, C.V. (2016). Determining heavy metal contamination of road dust in Delhi, India. Atmósfera 29: 221-234. https://doi.org/10.20937/ATM.2016.29.03.04

Taghavi, S.N., Kamani, H., Dehghani, M.H., Nabizadeh, R. and Afshari, N. (2019). Assessment of heavy metals in street dusts of tehran using enrichment factor and geoaccumulation index. Health Scope 8: e57879. https://doi.org/10.5812/jhealthscope.57879

Taiwo, A.M., Awomeso, J.A., Taiwo, O.T., Oremodu, B.D., Akintunde, O.O., Ojo, N.O., Elegbede, O.O., Olanrewaju, 
H.H. and Arowolo, T.A. (2017). Assessment of health risks associated with road dusts in major traffic hotspots in Abeokuta metropolis, Ogun state, southwestern Nigeria. Stochastic Environ. Res. Risk Assess. 31: 431447. https://doi.org/10.1007/s00477-016-1302-y

Tanushree, B., Chakraborty, S., Bhumika, F. and Piyal, B. (2011). Heavy metal concentrations in Street and Leaf Deposited Dust in Anand City, India. Res. J. Chem. Sci. 1: 61-66.

Tchounwou, P.B., Yedjou, C.G., Patlolla, A.K. and Sutton, D.J. (2012). Heavy Metal Toxicity and the Environment, In Molecular, clinical and environmental toxicology: Volume 3: Environmental toxicology, experientia supplementum, Luch, A. (Ed.), Springer, Basel, pp. 133164. https://doi.org/10.1007/978-3-7643-8340-4_6

Trojanowska, M. and Świetlik, R. (2016). To assess the exposure of urban residents to heavy metals present in street dust. Buses 12: 474-478. (in Polish)

Ukah, B.U., Egbueri, J.C., Unigwe, C.O. and Ubido, O.E. (2019). Extent of heavy metals pollution and health risk assessment of groundwater in a densely populated industrial area, Lagos, Nigeria. Int. J. Energy Water Res. 3: 291-303. https://doi.org/10.1007/s42108-019-00039-3

Van der Gon, H.A.C., Gerlofs-Nijland, M.E., Gehrig, R., Gustafsson, M., Janssen, N. and Harrison, R.M. (2013). The policy relevance of wear emissions from road transport, now and in the future-An international workshop report and consensus statement. J. Air Waste Manage. Assoc. 63: 136-149. https://doi.org/10.1080/109 62247.2012 .741055

Victoria, A., Cobbina, S.J., Dampare, S.B. and Duwiejuah, A.B. (2014). Heavy metals concentration in road dust in the Bolgatanga municipality, Ghana. J. Environ. Pollut. Hum. Health 2: 74-80. https://doi.org/10.12691/jephh-2-4-1

Wedepohl, K.H. (1995). The composition of the continental crust. Geochim. Cosmochim. Acta 59: 1217-1232. https://doi.org/10.1016/0016-7037(95)00038-2

Wu, Y., Lu, B., Zhu, X., Wang, A., Yang, M., Gu, S., Wang, X., Leng, P., Zierold, K., Li, X., Tang, K.K., Fang, L., Huang, R., Xu, G. and Chen, L. (2019). Seasonal variations, source apportionment, and health risk assessment of heavy metals in $\mathrm{PM}_{2.5}$ in Ningbo, China. Aerosol Air Qual. Res. 19: 2083-2092. https://doi.org/10.4209/aaqr.2 018.12.0452

Yang, T., Liu, Q., Li, H., Zeng, Q. and Chan, L. (2010). Anthropogenic magnetic particles and heavy metals in the road dust: Magnetic identification and its implications. Atmos. Environ. 44: 1175-1185. https://doi.org/10.1016/ j.atmosenv.2009.12.028

Received for review, February 3, 2020

Revised, June 2, 2020

Accepted, June 22, 2020 